\title{
Telecollaboration and genres: a new perspective to understand language learning
}

\section{Laura Rampazzo ${ }^{1}$ and Solange Aranha ${ }^{2}$}

\section{Abstract}

he purpose of this paper is to investigate the first 15 minutes of ten initial Teletandem Oral Sessions (iTOS), which means the first virtual encounter among speakers of

C different languages who want to study the each other's language. Our aim is to verify iTOS genre status within a telecollaborative learning environment. We understand genres as communicative events organized in standard structures used by members of a discourse community to achieve their communicative purposes (Swales, 1990) and assume that the teletandem context is composed of a specific community with shared objectives. A study of iTOS had first been proposed by Aranha (2014), who analyzed nine iTOS and identified some recurrence in their discoursal structure. Our data, ten iTOS, are part of a previous version of MulTeC (Multimodal Teletandem Corpus) (Aranha \& Lopes, forthcoming) and participants are proficient in Portuguese and English. The video files were transcribed and the sessions were analyzed based on Aranha's (2014) findings. We identified rhetorical organization for the sessions which was similar to Aranha's, but varied depending on the learning scenarios, i.e. the learning context in which they occurred.

Keywords: English-Portuguese interaction, telecollaboration, genres, rhetorical organization, learning scenarios.

\footnotetext{
1. Federal Institute of Education, Science and Technology of São Paulo (IFSP), Coordination for the Improvement of Higher Education Personnel (CAPES); laura.rampazzo@ifsp.edu.br

2. São Paulo State University, São Paulo Research Foundation (FAPESP); solange.aranha@unesp.br
}

How to cite this article: Rampazzo, L., \& Aranha, S (2019). Telecollaboration and genres: a new perspective to understand language learning. Journal of Virtual Exchange, 2, 7-28. https://doi.org/10.21827/jve.2.35637 


\section{Introduction}

The term telecollaboration, also known as 'virtual exchange', refers to the participation of learners in virtual intercultural interactions and collaboration projects with students from other cultural contexts or learners who are geographically distant; these are usually integrated to their educational programs (O'Dowd, 2018). One of the first uses of the word telecollaboration was in Warschauer's (1996) volume that compiled works on Computer Mediated Communication (CMC) presented the year before in a symposium held in Hawaii. Belz (2003) later developed the concept in order to describe the institutionalized use of Internet communication tools by students who are located in different places and want to develop their linguistic competence in a foreign language and their intercultural competence.

Currently, many telecollaborative projects around the globe are promoting virtual exchange experiences. Teletandem Brasil - Línguas estrangeiras para todos (Telles, 2006) is one of them. In teletandem, we have an individual who wants to learn the language of the other - mostly university students in Brazil learning a foreign language at UNESP (Sao Paulo State University) and students from universities abroad who want to practice Portuguese. Pairs of students meet every week via synchronous communication tools, mainly Skype ${ }^{\circledR 3}$ (see Cavalari, 2018, p. 425) for iTOS. Based on tandem language learning (Brammerts, 1996), its practice involves three principles as shown in the Table 1 below.

\section{Table 1. Teletandem principles (based on Vassallo \& Telles, 2006)}

\begin{tabular}{|l|l|}
\hline Teletandem principles & What they mean \\
\hline Separation of languages & $\begin{array}{l}\text { The length of an oral session should be divided into two equal parts so that both } \\
\text { participants get the same amount of time to practice their target language. In a } \\
\text { 50-minute session of a Portuguese-English partnership, for instance, 25 minutes should } \\
\text { be dedicated to speaking Portuguese and 25 to English. In Brammerts (1996), this } \\
\text { principle is embedded in the reciprocity principle. However, given its importance to the } \\
\text { practice, Vassallo and Telles (2006) opted for turning it into a separate principle. }\end{array}$ \\
\hline Autonomy & $\begin{array}{l}\text { Participants are autonomous enough to define their own learning } \\
\text { goals and the strategies for reaching them. }\end{array}$ \\
\hline Reciprocity & $\begin{array}{l}\text { Students are expected to equally invest in their partners' learning and reverse in } \\
\text { the roles of learner of a target language and tutor of their own language. }\end{array}$ \\
\hline
\end{tabular}

On the one hand, these principles should always be present in any teletandem practice as proposed by Telles (2006). On the other, the development of the activity has culminated in different modalities, among which lies the institutional integrated TeleTanDem (iiTTD) (Aranha \& Cavalari, 2014; Cavalari

3. https://www.skype.com/en/ 
\& Aranha, 2016). In iiTTD, two universities establish a partnership and teletandem is incorporated into foreign language courses at both institutions. Another characteristic of iiTTD is that partners are enrolled in language courses and all participants meet at the same time in an appropriate environment, such as a teletandem laboratory, during their language lessons. Professors on both sides are responsible for arranging the specifics before the first session takes place. Participation in iiTTD is mandatory and students are graded on some of the tasks requested by their professors.

Genres, from a socio-rhetorical perspective, are organized in rhetorical moves, i.e. the argumentative parts of a text that fulfill a rhetorical function that tend to recur in different exemplars of a genre. Therefore, it is argued in this paper that the iTOS might also be organized in moves by its participants and be considered a genre not only because it is a social interactive activity whose aim is shared, but also because rhetorical occurrence and linguistic features are expected. Aranha (2014) suggests that the recurrence of moves in the first encounter reveals that participants identify the need to establish contact and that the iTOS gives support to the following sessions. Therefore, the organization of the first session may contribute to the success of partnerships. Based on Miller (1984), we believe that learning about a genre may help understanding how knowledge is built in a community, thus, studying iTOS from a genre perspective may contribute to the development of such learning environments as well.

With respect to the investigation of genre in telecollaborative contexts, it should be mentioned that, although there has been an increasing interest in telecollaboration boosted by technological advances in communication tools and now a vast literature in the field (Dooly \& O'Dowd, 2018), very few initiatives combine telecollaboration and genre theories (Aranha, 2014; Aranha \& Leone, 2017; Rampazzo \& Aranha, 2018)

Aranha (2014) presents a pioneer study to the field of telecollaboration by associating teletandem with a genre theory in iiTTD. According to her, this modality seems to be favorable to the occurrence of genres that already exist in other environments and communities, as well as to the emergence of new ones, such as iTOS, the virtual weekly encounter. The practice is arranged in recurrent and regulated tasks, which implies that all participants tend to produce texts and communicative events in similar ways. Based on the notion that genres are standardized communicative events used by a discourse community (Swales, 1990), we agree with Aranha (2014) that iiTTD could constitute a system of genres that interrelate in order to achieve the purposes of the teletandem community (Silva, 2012).

4. Searches for the combinations genre + telecollaboration or its variations -tandem, teletandem, virtual exchange, online exchange, virtual connection, globally networked learning, online interaction and exchange (Dooly \& O'Dowd, 2018) - in scientific citation indexing services return only one result in Brazil (Rampazzo \& Aranha, 2018). 
Similarly to Aranha (2014), who analyzed the first minutes of nine iTOS and identified some recurrences in their discoursal structure, in this study, the analysis of ten iTOS is presented with the aim of identifying its rhetorical structure and reinforcing its genre status. The general goal of this work is to contribute to the investigation of the possible genres that co-occur in the telecollaborative context under study. The research question that guided this inquiry is 'which rhetorical structure(s) (if any) appear(s) in the first 15 minutes of iTOS?'.

\section{Telecollaboration: teletandem and learning scenarios}

Telecollaboration has been the common term used to refer to practices that connect language learners in pedagogically structured interactions enabled by online communication tools (Dooly \& O'Dowd, 2018). According to O'Dowd (2018), e-tandem and teletandem would be similar terminology since they both can be considered "subject-specific virtual exchanges", that is, "foreign language learning initiatives” (p. 6) aiming at developing foreign language and intercultural communicative competence.

Teletandem practice may be distinct depending on whether it is institutionalized (i.e. institutions support and promote it) and whether it is integrated into foreign language courses. Institutional integrated teletandem (Aranha \& Cavalari, 2014) means that two institutions arrange a partnership and the language professors agree to include the practice into their language course syllabi.

Within iiTTD, tasks are included to help promote learning. Helm and Guth (2010) explain that telecollaboration usually blends online and face-to-face learning contexts and tend to adopt taskbased language learning approaches, having learners work towards a specific goal. According to Aranha and Leone (2016, 2017), teletandem practice is organized in two macro-tasks: iTOS and mediation sessions. Within the macro-tasks, there are some tasks as well as micro-tasks, as shown in Figure 1. In iTOS, there are the oral sessions themselves, i.e. the virtual encounters via Skype® that may vary in quantity, and the micro-tasks that feed them: tutorial and text exchanges. The tutorial is a face-to-face meeting held with participants, usually from both institutions, whose aim is to explain what teletandem practice entails and present some theoretical background. It always occurs prior to iTOS. The text exchange is also connected to the oral sessions because, apart from writing texts in the target language and sending them to their partners for corrections/suggestions, participants are expected to use the outcomes as input for the following session.

Associated to the mediation sessions, there are the learning diaries, also named 'reflective diaries' in other papers (Aranha \& Cavalari, 2014; Aranha, Luvizari-Murad, \& Moreno, 2015; Cavalari \& 
Aranha, 2016), and the final questionnaire. The mediation session itself is a face-to-face meeting regularly held with participants (usually every other week), in which students and their professor talk about their learning process and difficulties during iTOS and share any other issues arisen in the diaries. The learning diary is a reflective practice in which students write about their experience, the obstacles they have been encountering, the achievements they have had, and the learning strategies they have been using. Students also respond to two questionnaires - an initial and a final one. In the former, students self-assess their language level based on the Common European Framework of Reference for languages (CEFR) and establish their learning goals for teletandem, and, on the latter, they comment on their experience and may include suggestions.

Figure 1. The organization of a pedagogical scenario based on teletandem (Aranha \& Leone, 2017)

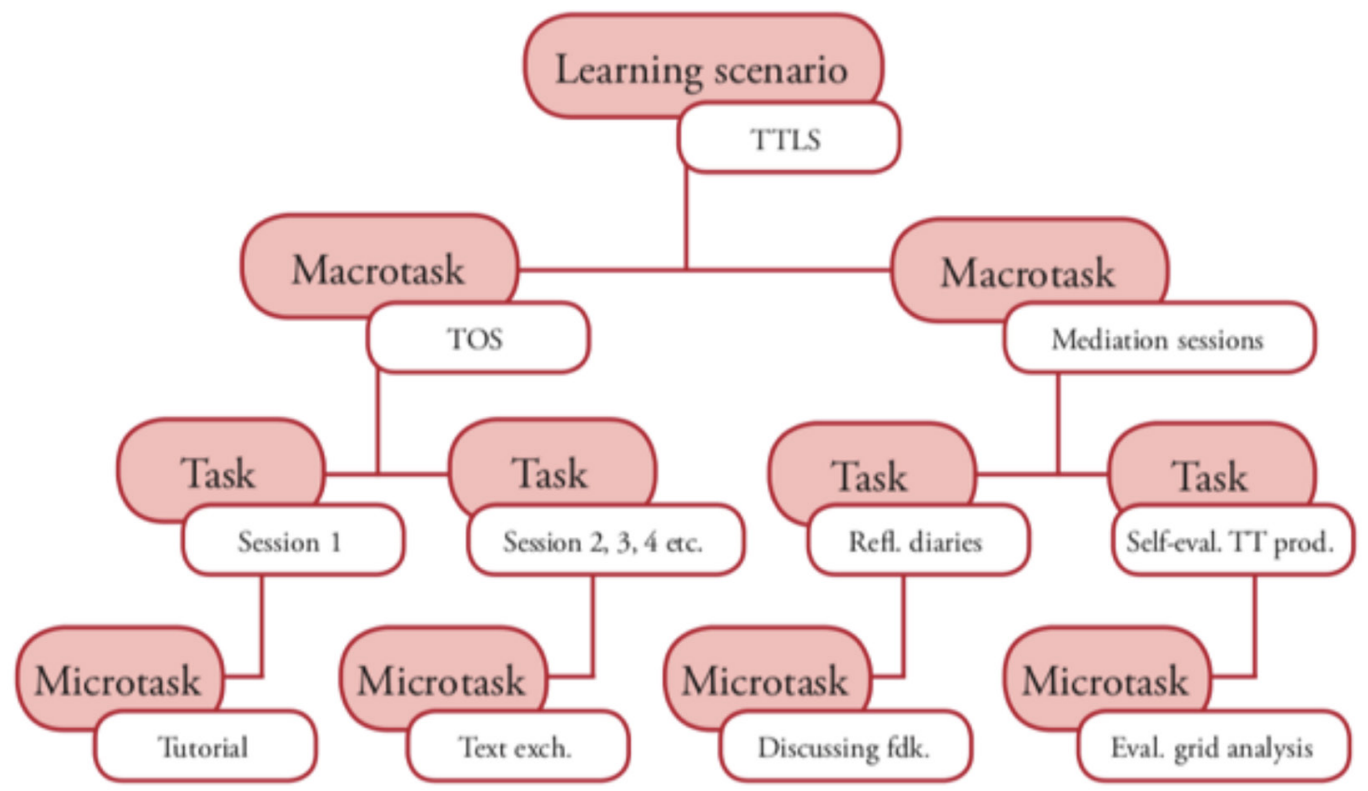

Tasks and micro-tasks in teletandem may vary from one experience/group to another. In Brazil, every semester there are various classes participating in teletandem with singular characteristics - the learners and tasks differ from one group to another. Recently, studies have been referring to specific groups as different learning scenarios (Aranha \& Leone, 2016, 2017), a concept that appears in Foucher (2010) and has been adapted to this telecollaborative project by Aranha and Leone $(2016,2017)$. 
The concept of learning scenarios is complementary to the definition of pedagogical scenarios (Foucher, 2010). The pedagogical scenario is used to describe what has been planned for a learning situation and includes the goals and competences students have prior to the task and the competences they may develop. The learning scenario describes what happens in the real learning situation; it is the description of what actually occurs in a given learning context.

Aranha and Leone (2016) adapt the definition of learning scenario to teletandem in order to describe the tasks that are carried out, the participants, the interaction typology, and the length of sessions. Therefore, the description of a teletandem learning scenario involves listing the tasks and dates, the partner institutions, the students (their age, gender, university major), interaction typology, and amount of sessions. We may argue that, for each established teletandem partnership, there is a different learning scenario. We may also suggest that participants carry out their tasks in similar ways for the same learning scenario, but could develop them differently if the scenario changed.

Based on previous works (Aranha, 2014; Rampazzo \& Aranha, 2018), we believe the organization and development of tasks in iiTTD may constitute a genre system. Therefore, the next section presents the genre definition adopted in this work and how it relates to CMC.

\section{Genres and CMC}

We adopt the definition of genre as a social action that shapes human actions and occurs in a recurrent context (Miller, 1984). Genre is also seen as a result of the communicative needs of a discourse community whose members develop standardized rhetorical structures in order to achieve their communicative purposes (Swales, 1990). As Miller (1984) states, "the understanding of rhetorical genre that I am advocating is based in rhetorical practice, in the conventions of discourse that a society establishes as ways of 'acting together'” (p. 163), which means that a community defines similar ways of doing things in order to generate and share knowledge.

Bazerman (1994) explains that people identify a recognizable circumstance and tend to associate forms of expression that seem to be more socially appropriate or effective for the rhetorical problems they are facing. Therefore, genres could also be defined as "recognizable textual forms deployed in recognizable circumstances” (Bazerman, 1994, p. 18). In case of teletandem, we may suggest that participants perceive that learning situation as similar to other communicative events and apply certain solutions that have been successful in so-called analogous environments. 
Few studies combine genre and telecollaboration. However, some genre studies that relate to CMC or multimodality emphasize the dynamic nature of genres - already discussed in Swales $(1990,2004)$ and Bazerman (2009), among others. Genres evolve in response to changes in the communicative context, which also includes changes in medium (Hafner, 2018). Hafner (2018) also argues that the use of digital media to meet the needs of a community can lead to the development of genres. In other words, we argue that the context and communicative needs of those involved in teletandem environments might lead to the creation and use of recurrent patterns of action.

According to Swales (1990), genres are organized in rhetorical moves - parts of a text that (intend to) fulfill a function. Recently, Moreno and Swales (2018) discussed the move analysis proposed by Swales (1990) and explained that a move is a rhetorical construct (1) whose linguistic realization may vary, (2) whose purpose is realized by one or more specific functions, named by Swales (1990) as steps, and (3) whose boundaries (between moves) may be imprecise. In 2009, Swales states that genres can have a structure that works as a model, a prediction of what could be expected from texts from a certain genre. The most common moves would integrate the prototypical structure of a genre.

Observing that participants seemed to organize their discourse in teletandem in similar ways, Aranha (2014) carried out an analysis of the first 15 minutes of nine iTOS. Despite not using the term rhetorical move, the author identifies five recurrent parts of discourse in the analyzed sample: (1) technical issues; (2) name exchange; (3) age exchange; (4) places and roommates; and (5) academic life.

This present investigation shows the analysis of data from a genre perspective. It provides an investigation of ten other iTOS, replicating Aranha's (2014) study on the moves, and implements a discussion that relates the rhetorical structure of the session and the learning scenario in which it occurred. The analysis procedures are detailed in the next section.

\section{Methodology}

The research presented in this paper combines qualitative and quantitative approaches, presenting itself as a mixed methods research (Dörnyei, 2007). The qualitative aspect of this study is more evident because our discussion is a result of data interpretation, that is, the identification of the rhetorical structure of iTOS was determined by the analysts. iTOS were segmented into functionally meaningful sections. In regard to the move analysis, Moreno and Swales (2018) point out that it needs to be done manually as it is an interpretation of communicative functions. They state that the 
move categories presented by the analysts are based on rhetorical content. The quantitative aspect of this research lies in determining the recurrence of each move.

\subsection{Data}

Data for this research are composed of the first 15 minutes of ten iTOS, referred to as iTOS1, iTOS2, iTOS3, etc. They come from a previous version of MulTeC (Aranha \& Lopes, forthcoming), a corpus that includes data from a partnership established between a university in Brazil (Sao Paulo State University - UNESP) and a university in the United States (University of Georgia - UGA). Such data comprehend iTOS, tutorial PowerPoint ${ }^{\circledR}$ slides, pedagogical and learning scenario documents, texts written and revised by students, learning diaries, chat registers of the sessions, and the initial and final questionnaires, i.e. every and each genre within the system which are likely to be studied based on multiple theoretical perspectives, including genre theories. MulTeC includes data collected from 2012 to 2015 in Portuguese/English partnerships: 567 hours, 14 minutes and 18 seconds of recorded iTOS, 646 learning diaries, 132 questionnaires, 921 texts written by the participants and 355 chat registers of 277 students that signed the consent form, approved by the Research Ethics Committee at UNESP, authorizing the use of their image and/or data for research - 122 from UNESP and 155 from UGA (Aranha \& Lopes, forthcoming).

Our data are composed of three initial oral sessions from $2011^{5}$, two from 2012, two from 2013, and three from 2014. This research comprises six participants from 2011 (three pairs), four from 2012 (two pairs), four from 2013 (two pairs), and six from 2014 (three pairs). We selected the files based on the quality of the video recordings available, no other criteria was applied.

In regard to the students involved in this research, 19 were undergraduate students. In the American university, they were enrolled in the Portuguese course, however, they had different majors and one was a PhD student. In Brazil, all ten participants were undergraduate students of Language Education for Teaching Foreign Languages. The previous version of MulTeC ${ }^{6}$ we used had not been organized, so we lack some information about the participants, such as age. Gender was determined by researchers based on video recordings and, coincidently, for the first session, students were paired up with people from the same gender as them (three male pairs and seven female ones). Students self-evaluate their language level based on CEFR.

5. The researchers who organized MulTeC opted to exclude data from 2011 because the majority of the files from that year had been corrupted by the time MulTec was organized into a corpus (Lopes, 2019). However, the study presented here was conducted concomitantly to the corpus organization and we decided to keep the three oral sessions from 2011.

6. Chat was not taken into account for this research. 
Participants used Skype ${ }^{\circledR}$ for the sessions and had the opportunity to eventually use the chat. Because the oral session files were available in mp4 format, we first transcribed them. The demonstration version of Transana ${ }^{\circledR}$, a software that allows researchers to make annotations for video files, was used for the transcription. Later, we copied the transcription and pasted it into a Word® file. The transcription procedures suggested by Marcuschi (2003) and Gonçalves and Tenani (2008) were used and their annotation model ${ }^{7}$ was adapted. The ten sessions transcribed resulted in a total of 55, 600 words. In order to proceed with our analysis of the first 15 minutes, the portion of the texts that corresponded to it was selected: 16,687 words.

Based on the definition of learning scenarios, the sessions would give us four distinct scenarios, as the participants, the arrangements, the tasks, and expectations were different and specific. However, because of the similarities among the sessions that occurred in 2011, 2012, and 2013, and for analytical purposes, we combined these seven sessions into one learning scenario, named here as Learning Scenario A.

All sessions from this scenario were of alternate monolingual interaction typology, all Brazilian participants' majors was languages, they all had to exchange texts beginning in the second oral session, and students were paired in the iTOS depending on the computers chosen on the first day, which were already logged on a Skype account.

The three sessions from 2014 were included into a Learning Scenario B. These share almost all the characteristics of the ones from Scenario A, except that students had been randomly paired prior to iTOS and the participants from the American university had sent their Brazilian partners an introductory text written in Portuguese before they met online.

As Figure 2 illustrates, the sessions from scenarios in 2011, 2012, and 2013 (Scenario A) resembled each other, and the major difference between them and the sessions from 2014 (Scenario B) is related to the previous pairing and text exchange from day one.

Apart from the iTOS, the tutorial files for each year, as well as the initial questionnaire answered by the Brazilian participants were taken into consideration. These files provided a more thorough description of the learning scenarios as the PowerPoint presentation used in the tutorial meeting includes information about the tasks participants need to fulfill and the calendar of interactions.

7. Appendix. 
Figure 2. Investigated learning scenarios

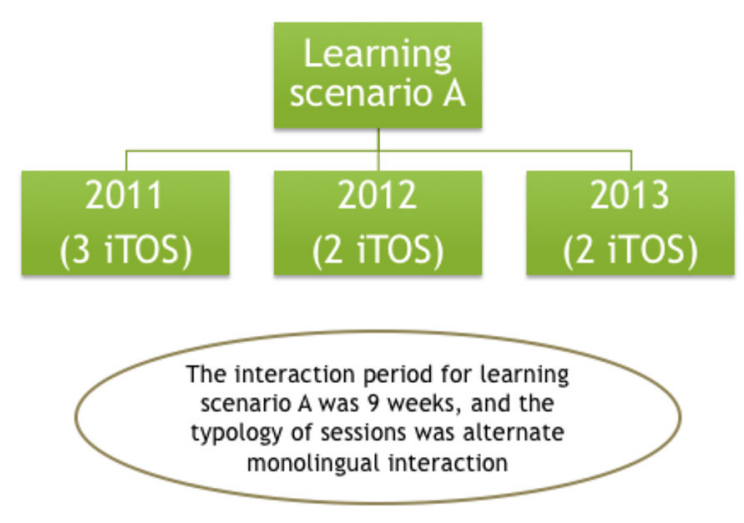

Learning

scenario B

2014

(3 iTOS)

\subsection{Analysis procedures}

The goal of this paper is to investigate iTOS rhetorical structures based on Swales's (1990) proposal to define the prototypical rhetorical structure of a genre investigating the recurrent moves in texts directed to specific discursive communities. In order to identify the rhetorical moves, the first step of the analysis was a reading of the data (transcripts of the oral sessions) in order to have an overview of iTOS structures, bearing in mind the previously identified purpose of the session: establishing initial contact and giving support to the following oral sessions (Aranha, 2014, p. 113). The identification of rhetorical moves and its boundaries was carried out manually based on our interpretation of their communicative functions of each part and also on the results that already existed in 2014. We understand that the reliability of move analysis in teletandem practice rely on the recurrence of the same moves in a broader sample.

Aranha (2014) made a first attempt to determine the iTOS rhetorical structure, identifying the recurrence of five items - discussion on (1) technical issues; (2) their names; (3) their ages; (4) the places where they lived and who they lived with; and (5) their academic life. She does not, however, determine if these items are considered moves or steps. Given the move definition -the argumentative parts that function to fulfill genre communicative purposes - items $b, c, d$, and $e$ of Aranha's (2014) investigation have a common function, the one of exchanging information. Therefore, we grouped the five items presented in Aranha (2014) into two different moves, a negotiation move (a), in which participants check if the equipment is working properly, and an information exchange move (b, c, d, and e). 
Finally, another step for the negotiation move - one in which participants decide on the language to speak for that part of the session - was noticed in almost all sessions. A third move in the sessions from Learning Scenario B that had not been found in the sessions from Scenario A - one in which participants discuss the texts written by the American students -was also identified. Because of this finding, the learning scenario characteristics were studied and checked for any relation to the moves; that is, the occurrence of the third move could be related to the tasks that were requested of students from Learning Scenario B.

\section{Results}

\subsection{General findings}

Results indicate that the first 15 minutes of the ten analyzed initial oral sessions were structured in rhetorical moves. This means that the discourse in iTOS is organized in rhetorical parts that are similar in content in each sample analyzed. Figure 3 illustrates the moves identified in each session for both learning scenarios under study - Sessions 1 to 7 belong to Learning Scenario A and Sessions 8 to 10 to Learning Scenario B. Each color represents a different move: in orange, the information exchange move is represented; in yellow, the negotiation move; and, in green, the text discussion move. The numbers (vertically displayed) indicate the extension of moves in each session, where $100 \%$ represents the total length of an iTOS. In iTOS2, for instance, for nearly $90 \%$ of the time participants stayed at the information exchange move (the orange bar almost reaches the $90 \%$ mark) and, in the other $10 \%$, they negotiated the language they would speak for that portion of the session (yellow bar going from approximately 90\% until 100\%).

Figure 3 illustrates that the two moves previously found in Aranha (2014) - the negotiation and the information exchange move - were present in our data. Apart from that, a third move was identified in Learning Scenario B, the one in which students discussed about formal language issues in the texts written in Portuguese by the students from UGA. We suggest that this move was only found in Learning Scenario B because of the contextual design of the learning scenario. There was not a predefined order for the moves to occur, although participants tended to present themselves first, for Scenario A, or confirm if they had been connected to the correct partner, for Scenario B - Sessions $1,3,4,5,6,7,8,9$, and 10 .

Each of the moves found in both scenarios was performed by different steps, the linguistic realization of a move. The table below demonstrates what could be considered the prototypical rhetorical structure for the scenarios. 
Figure 3. Moves identified in both scenarios in relation to time

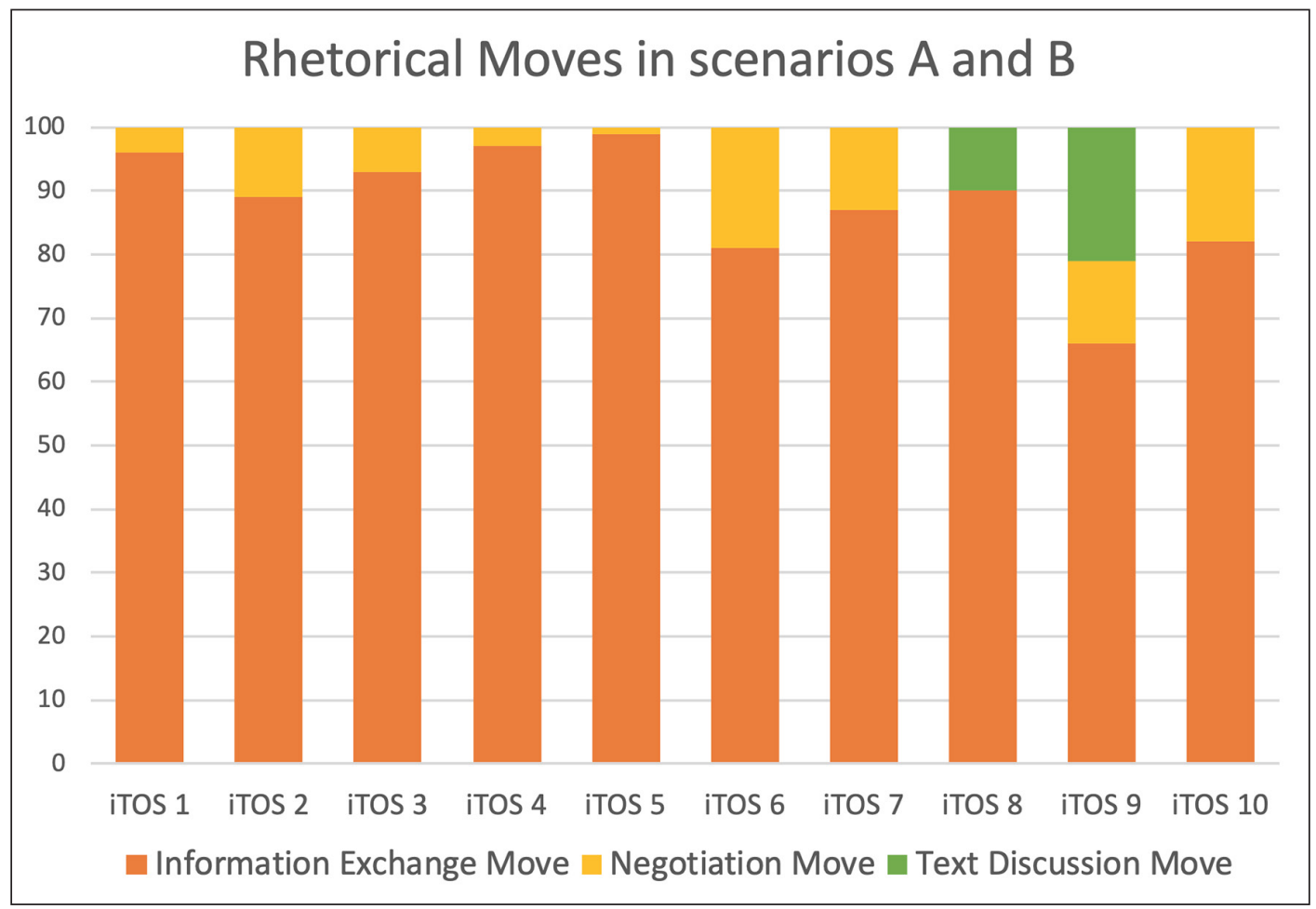

\section{Table 2. Prototypical moves for Learning Scenarios A and B}

Prototypical rhetorical structure for Learning Scenario A Prototypical rhetorical structure for Learning Scenario B

Negotiation move:

(a) testing the equipment; and/or

(b) choosing a language
Negotiation move:

(a) testing the equipment; and/or

(b) choosing a language; and/or

(c) finding the correct partner

Information exchange move:

(a) introductions and greetings; and/or

(b) information on the academic/professional life; and/or

Information exchange move:
(a) introductions and greetings; and/or
(b) information on the academic/professional life; and/or
(c) personal information - age, family,
interests, experience; and/or
(d) information on the countries and
places where they live; and/or
(e) information on language studies.

Text discussion move:

(a) Comments on formal language issues 
Table 2 suggests that, although very similar, the organization of the first 15 minutes of the iTOS may vary depending on the learning scenarios, a characteristic that will be further discussed.

\subsection{Learning Scenario A}

The negotiation move functions as a way of making sure communication will be possible and will follow the teletandem principles exposed during the tutorial. In Scenario A, negotiation was necessary to test the equipment, making sure it was working well, or to choose a language to talk in for that half of the session, considering the language separation principle. The equipment testing and the language definition are recognized as steps of the negotiation move and are optional and dependent upon the lab environment, as they did not appear in all iTOS from this scenario.

About the step of testing the equipment, it occurred in two different occasions: (1) when participants had trouble in making the equipment function well - a problem mentioned in Aranha (2014) and other studies on teletandem, such as Luz (2012), Garcia (2015), Freschi and Lopes (2016) - or (2) as a means of checking if everything was working and the communication would be possible. When students noticed there was a technological problem, they tended to negotiate or ask their professors for help so that they could resume their conversation, as the excerpt in Table 3 illustrates. In the excerpts, the letters B and E indicate different speakers. B stands in for Brazilian, and E for Foreign Participant ("Estrangeiro" in Portuguese). In the excerpts, participants' names were replaced with a code ${ }^{8}$.

\section{Table 3. Excerpt from iTOS 3}

\begin{tabular}{|l|l|}
\hline $\begin{array}{l}\text { B: [[talks to someone in the laboratory]] eu não sei. } \\
\text { [[she types]] você me ouve? [[Brazilian participant } \\
\text { talks and types on chat]] acho que não }\end{array}$ & $\begin{array}{l}\text { B: [[talks to someone in the laboratory]] I don't know. } \\
\text { [[she types]] can you hear me? [[Brazilian participant } \\
\text { talks and types on chat]] I don’t think so }\end{array}$ \\
\hline E: sim [[types]] & E: yes [[types]] \\
\hline $\begin{array}{l}\text { B: mas eu não escuto, o meu tá super baixinho } \\
\text { [[inaudible]] eu já aumentei aqui [[technician works } \\
\text { on Skype settings]] Oi, você tá me ouvindo? }\end{array}$ & $\begin{array}{l}\text { B: but I can’t hear, it’s super low [[inaudible]] I } \\
\text { have already put the volume up here [[technician } \\
\text { works on Skype settings]] Hi, can you hear me? }\end{array}$ \\
\hline E: ah olá oi & E: ah hello hi \\
\hline B: agora eu to te ouvindo & B: I can hear you now \\
\hline E: oi, tá tá bom agora? & E: hi is it good now? \\
\hline B: tá tá tá bom & B: yes yes yes it’s good \\
\hline Original occurrence & Translated version \\
\hline
\end{tabular}

8. See Aranha and Lopes (forthcoming) for information about coding/anonymisation. 
As mentioned, other occurrences of this step were not related to problems or technical issues, but were a way of participants making sure they would be able to talk without problems (Table 4).

\section{Table 4. Excerpt from iTOS 4}

E: Can you hear me?

B: yes and you?

E: Good I can hear you fine

This step of the negotiation move usually appeared in the beginning of the session - Sessions 1, 3, 4-, except when there were technical issues along the interaction. Another step of negotiation choosing a language - also appeared in the beginning. Commonly, participants would negotiate the language they would use for the first half of the session after introducing themselves and making sure the equipment was working. Students would usually ask their partners what they would prefer to do (Table 5).

\section{Table 5. Excerpt from iTOS 4}

B: oh! ok... we can... can we start eh to talk in English or Portuguese? what you prefer?

E: I.. it does not matter whatever you like

B: oh ok in English [[laughs]]

E: in English ok [[laughs]]

The fact that students would not decide on their own which language to speak and expect their partners to simply go along with their decision demonstrates they were attentive to the principles of separation of languages as well as reciprocity, for they would not impose a language, but rather negotiate with the partner. This indicates they believe they are equals and should respect each other's opinions. Although in intercultural exchanges such as teletandem, participants practice both languages of a partnership in a sequential manner, the order of occurrence is not previously set by a professor, which obliges negotiation.

The information exchange move was the most extended one. In Scenario A (Sessions 1-7), most of the time was dedicated to exchanging information (see Figure 3, the move extension is represented in orange), compared to negotiating an issue (represented in yellow in Figure 3). The information exchange move presented a wider variety of possibilities for linguistic realization of a move (Table 2). In the samples, the information exchange moves were performed by five steps: (1) introductions and greetings; (2) information on the academic/professional life; (3) personal information - age, family, interests, experience; (4) information on the countries and places where they live; and (5) information on language studies, i.e. in order to exchange information, learners would introduce 
themselves and greet each other, talk about their academic or professional life, exchange personal information, such as informing their age, talking about family, interests, and past experience, speak about the countries and places they lived in, and/or talk about their experience learning a language. In this regard, in another paper (Rampazzo \& Aranha, 2018), we argued it was possible to find nine different steps for the information exchange move. However, we now understand that some of the items mentioned in the conversation correspond to the same step, such as personal information, family, personal interests, and experience.

The information move has the purpose of making the partners get to know each other, try to find things in common and find themes they consider interesting in order to establish and maintain contact. Participants also try to make positive contact and ensure they will have a pleasant relation for the duration of the partnership, usually greeting each other and stating it is a pleasure to meet one another.

\subsection{Learning Scenario B}

In Learning Scenario B (Sessions 8-10), negotiation and information exchange moves were also identified. The information exchange move was again the most extense (represented in orange in Figure 3), when compared to the negotiation move (represented in yellow in Figure 3) and the text discussion move (represented in green in Figure 3).

For the negotiation move (Table 2), there was a third step: searching for the correct partner. In this step, students tried to find the partner they were paired with before the iTOS. The misunderstandings in the beginning of the session were probably due to students getting connected to the wrong computer. Usually, when students arrive at the lab for a session, all Skype accounts are already logged in and they just need to wait for their partners' video call. In this case, they were possibly not attentive to the account logged into Skype and were connected to the wrong person. When this issue happened, students had to negotiate with each other so that they could get connected to the right partner. In the excerpt that follows, participants carry a long exchange in order to find their partners (Table 6).

Table 6. Excerpt from iTOS 10

\begin{tabular}{|l|l|}
\hline E1: oi! [[waves]] & E1: hi! [[waves]] \\
\hline B: oi! [[waves]] & B: hi! [[waves]] \\
\hline E1: wait I don't he/ok now... ah... é como você llama? & E1: wait I don’t he/ok now... ah... what's your name? \\
\hline B: I9F13 & B: I9F13 \\
\hline
\end{tabular}




\begin{tabular}{|c|c|}
\hline $\begin{array}{l}\text { E1: ok eu tenho que é encontrar meu par/ } \\
\text { parceiro I guess [[laughs]] }\end{array}$ & E1: ok I need to find my partner I guess [[laughs]] \\
\hline B: ah qual o nome dele? & B: what's his name? \\
\hline E1: é [[partner’s name]] & E1: it’s [[partner's name]] \\
\hline B: [[name]]... [[name]] não está aqui ainda & B: $[[$ name $]] . . .[[$ name $]]$ not here yet \\
\hline E1: ah [[sad expression]] & E1: ah [[sad expression]] \\
\hline B: ah acabou de chegar! acabou de chegar & B: ah just got here! Just got here \\
\hline E1: ok é... & E1: ok... \\
\hline $\begin{array}{l}\text { B: ah peraí [[to someone in the lab]] qual o número do } \\
\text { computador dela? [[to another student]] unesp15 ela está }\end{array}$ & $\begin{array}{l}\text { B: ah hold on [[to someone in the lab]] what's her computer } \\
\text { number? [[to another student]] unesp15 she is }\end{array}$ \\
\hline E1: [inaudible] ok e... eu e agrego a ela? ou? & E1: [inaudible] ok and... I add her? or? \\
\hline $\begin{array}{l}\text { B: ah não sei eu acho que ela já está conectada em } \\
\text { algum outro computador [E: ah ok] você tem trocar }\end{array}$ & $\begin{array}{l}\text { B: ah I don't know I think she is connected to } \\
\text { another computer [E: ah ok] you need to trade }\end{array}$ \\
\hline E1: eu vou eu vou ah é... [[points to other computers]] & E1: I and I am ah... [[points to other computers]] \\
\hline B: o parceiro chama U0F23 & B: the partner is called U0F23 \\
\hline E1: como? & E1: how? \\
\hline B: eu acho que é U0F23 ah não sei como se pronuncia & B: I think it is U0F23 ah I don't know how to pronounce \\
\hline E1: U0F23? U0F23! & E1: U0F23? U0F23! \\
\hline B: U0F23 com [[says a letter from her partner's name]] & B: U0F23 with [[says a letter from her partner's name]] \\
\hline E1: [[repeats the letter]]? & E1: [[repeats the letter]]? \\
\hline B: [[says the letter in English pronunciation]] U0F23 & B: [[says the letter in English pronunciation]] U0F23 \\
\hline $\begin{array}{l}\text { E1: [[looking confused. To someone in the lab]] U0F23? } \\
\text { who? the blond who the blond? who? oh the blonde girl? } \\
\text { [[to the Brazilian girl]] ok um momento [[leaves]] }\end{array}$ & $\begin{array}{l}\text { E1: [[looking confused. To someone in the lab]] U0F23? } \\
\text { who? the blond who the blond? who? oh the blonde } \\
\text { girl? [[to the Brazilian girl]] ok a moment [[leaves]] }\end{array}$ \\
\hline B: ok [[laughs]] & B: ok [[laughs $]]$ \\
\hline$\ldots$ & $\ldots$ \\
\hline $\begin{array}{l}\text { B: [[to someone in the lab]] eu peguei a parceira } \\
\text { da [[name }]] . . .[[U 0 F 23 \text { comes to screen]] }\end{array}$ & $\begin{array}{l}\text { B: [[to someone in the lab]] I got [[name]]'s } \\
\text { partner... [[U0F23 comes to screen]] }\end{array}$ \\
\hline E: oi & E: hi \\
\hline B: oi! você? & B: hi! you? \\
\hline E: eu sou/sim eu sou U0F23 & E: I am/ yes I am U0F23 \\
\hline B: U0F23 ah... eu a I9F13 & B: U0F23 ah... I am I9F13 \\
\hline Original occurrence & Translated version \\
\hline
\end{tabular}

As the occurrence in Table 6 illustrates, students were paired in advance and, when they arrived at the labs, they made mistakes in connections, ending up being fixed to a mistaken partner. This step of the negotiation move is exclusively related to the characteristics of Learning Scenario B because only in this scenario students were previously paired and were supposed to find their right partners. 
Also related to the scenario characteristics was the occurrence of the introduction and greetings step of the information exchange move. While in Learning Scenario A students would ask their names when they first saw each other, in Scenario B they would say each other's names, which might indicate they were trying to confirm if they had been connected to the right person (Table 7).

\section{Table 7. Excerpt from iTOS 8}

\begin{tabular}{|l|l|}
\hline E: oi, I9M4 & E: hi, I9M4 \\
\hline B: oi, U0M14 & B: hi, U0M14 \\
\hline E: sim sim tudo bem? & E: yes yes how are you? \\
\hline B: tudo bem e você? & B: I'm fine and you? \\
\hline $\begin{array}{l}\text { E: todo bem muito obrigado por ah todas as } \\
\text { suas correcciones de mi composição }\end{array}$ & E: fine thank you for ah all of your corrections in my text \\
\hline Original occurrence & Translated version \\
\hline
\end{tabular}

In the excerpt above, students say their partners' names and also confirm their names ("yes yes"), which is probably a way of assuring they had the correct partners.

Finally, a third move was identified - the text discussion move - which is directly connected to the characteristics of the scenario as well. In Learning Scenario B, American students sent a text written in Portuguese prior to iTOS. According to the information in the tutorial, students were advised not only to revise and write comments on their partner's text but also to talk about the text in the oral session. In the excerpt presented in Table 8, students followed the suggestions and used a few minutes of iTOS to make observations on the text.

\section{Table 8. Excerpt from iTOS 10}

\begin{tabular}{|c|c|}
\hline B: você viu a correção que eu fiz da redação? & B: have you seen my correction of your text? \\
\hline E: sim! muito [B: tem pouco] sim & E: yes! A lot [B: there are few] yes \\
\hline $\begin{array}{l}\text { B: é, como eu falei tem poucos erros, você errou } \\
\text { mais na questão de é se é feminina ou masculina } \\
\text { na hora de colocar o final da palavra }\end{array}$ & $\begin{array}{l}\text { B: well, it’s like I told you, you made mistakes } \\
\text { about the nouns if they are feminine or masculine } \\
\text { when writing the end of the word }\end{array}$ \\
\hline E: $\operatorname{sim}$ & E: yes \\
\hline $\begin{array}{l}\text { B: mas mas a redação é boa, aí eu deixei } \\
\text { em negrito algumas palavras que... }\end{array}$ & $\begin{array}{l}\text { B: but but your text is good, some of the } \\
\text { words I highlighted in bold }\end{array}$ \\
\hline$[\ldots]$ & {$[\ldots]$} \\
\hline $\begin{array}{l}\text { B: é dificultar ou uma expressão maior seria criar } \\
\text { obstáculos, que é o sentido da palavra né que é você... } \\
\text { é equivalente é empeçar seria dificultar, atrapalhar }\end{array}$ & $\begin{array}{l}\text { B: yeah making it difficult or a stronger expression would } \\
\text { be create obstacles, which is the meaning of the word } \\
\text { you... it is equivalent to make it difficult, cause trouble }\end{array}$ \\
\hline
\end{tabular}


E: sim... então sim, eu penso que/eu acho que entendi todos ah.. todas as correcções sim [[they laugh]]

Original occurrence
E: yes, so yes I think I tink I understand all ah... of your corrections yes [[they laugh]]

In the text discussion move, we could only identify one step, named here as 'comments on formal language issues' (Table 2). When talking about the written production, students seem to restrict their comments to formal aspects, stating what could be considered the most appropriate use of the language.

In the data analyzed for this research, the recurrence of two moves in the sessions from Learning Scenario A and three moves in the sessions from Learning Scenario B were identified. Having presented the results, in the next section, we discuss our findings and present our conclusions.

\section{Discussion and conclusions}

The first 15 minutes of each of the ten sessions analyzed for this paper were organized in rhetorical moves that recurred in the other sessions of our corpus. Despite the different learners involved in the partnerships and interactions, students on teletandem organize their discourse in the beginning of the initial oral session in similar manners. That is, the first 15 minutes of the initial synchronous virtual encounter seem to be going through a process of standardization as students perceive this situation as similar to others and start using certain rhetorical responses, obtained through the use of specific textual features.

Aranha (2014) had already pointed out that there could be a rhetorical structure for iTOS. In this research, we were also able to identify the recurrence of moves in the first minutes of iTOS and therefore we argue that there is rhetorical standardization in the discourse of iTOS. Based on Swales's (1990) conception of a genre being organized in rhetorical parts of a text that provide the information needed in order to fulfill a function and contribute to achieving its communicative purpose, this study contributes to the understanding of the iTOS as a genre, even though more studies are needed. We argue that there is enough evidence in that direction because it is a communicative event with a communicative purpose - exchanging information in order to get to know each other, as stated in Aranha (2014) and Rampazzo (2017), it is an event that occurs within a discourse community, the teletandem community (Silva, 2012); and it has a standard rhetorical structure for its initial 15 minutes.

We could argue that there is not only one prototypical structure for the iTOS, but prototypical structures that may vary according to the peculiarities of the learning scenario because, as Table 2 
illustrates, a third move was identified in Scenario B, one related to a task requested only in this scenario - the writing of a text in Portuguese prior to iTOS.

These findings also confirm that the context in which a genre occurs plays an important role to genre materialization, as argued by Swales (1990, 2004) and Bazerman (2009). The analyst should, then, pay close attention to the context in which a genre occurs as significant changes in the conditions in which the texts are produced may imply variation in the genre structure and materialization.

\subsection{Study limitations}

There were limitations to this study: (1) the investigation was restricted to the first 15 minutes of oral interaction; (2) the whole exchange has not been studied so far; and (3) inter-rated reliability was not calculated. Also, a greater number of sessions could have been investigated, even though, as Moreno and Swales (2018) discuss, most move analyses are done with small corpora as they are done manually.

\subsection{Further research avenues}

Further studies could be dedicated to the examination of the rhetorical structure of the total length of the iTOS, apart from the other intermediate and final sessions. Besides the oral sessions, other tasks that occur in the context could be investigated under a genre perspective in order to confirm if, together, they form a genre system in this telecollaborative environment.

\section{References}

Aranha, S. (2014). Os gêneros na modalidade de teletandem institucional integrado: a primeira sessão de interação. In E. L. Nascimento \& R. H. R. Rojo (Eds), Gêneros de texto/discurso e os desafios da contemporaneidade (pp. 97-117). Campinas: Pontes Editores.

Aranha, S., \& Cavalari, S. M. S. (2014). A trajetória do projeto Teletandem Brasil: da modalidade Institucional NãoIntegrada à Institucional Integrada. The ESPecialist, 35(2), 183-201.

Aranha, S., \& Leone, P. (2016). DOTI: Databank of oral teletandem interactions. In S. Jager, M. Kurek \& B. O’Rourke (Eds), New directions in telecollaborative research and practice: selected papers from the second conference on telecollaboration in higher education (pp. 327-332). https://doi.org/10.14705/rpnet.2016.telecollab2016.525

Aranha, S., \& Leone, P. (2017). The development of DOTI (Data of oral teletandem interaction). In D. Fiser \& M. Beibwenger (Eds), Investigating computer-mediated communication: corpus-based approaches to language in the digital world. (1st ed.) (pp. 172-190). Ljubljana: University Press, Faculty of Arts. 
Aranha, S., \& Lopes, Q. B. (forthcoming). The development of a multimodal corpus based on teletandem practice: a bumpy path.

Aranha, S., Luvizari-Murad, L., \& Moreno, A. C. (2015). A criação de um banco de dados para pesquisas sobre aprendizagem via teletandem institucional integrado (TTDii). Revista (Con)textos Linguísticos, 9(12), 274-293.

Bazerman, C. (1994). Constructing experience. Carbondale and Edwardsville: Southern Illinois University Press.

Bazerman, C. (2009). Atos de Fala, Gêneros Textuais e Sistemas de Atividades: como os textos organizam atividades e pessoas. In A. P. Dionísio, A. Paiva \& J. C. Hoffnagel (Eds), Gêneros textuais, tipificação e interação (3rd ed.) (pp. 1946). São Paulo, SP: Cortez.

Belz, J. A. (2003). Linguistic perspectives on the development of intercultural competence in telecollaboration. Language Learning \& Technology, 7(2), 68-99.

Brammerts, H. (1996). Tandem language learning via the internet and the International e-mail tandem network. In D. Little \& H. Brammerts (Eds), A guide to language learning in tandem via the internet (pp. 9-21). CLCS Occasional Paper, 46. Dublin: Trinity College.

Cavalari, S. M. S. (2018). Integrating telecollaborative language learning into Higher Education: a study on teletandem practice. BELT: Brazilian English Language Teaching Journal, 9(2), 417-432.

Cavalari, S. M. S., \& Aranha, S. (2016). Teletandem: integrating e-learning into the foreign language classroom. Acta Scientiarium: Language and culture, 38(4), 327-336.

Dooly, M., \& O’Dowd, R. (2018). Telecollaboration in the foreign language classroom: a review of its origins and its applications to language teaching practice. In this together: teachers' experiences with transnational, telecollaborative language learning projects, 1(s.n.), 11-34.

Dörnyei, Z. (2007). Research methods in applied linguistics: quantitative, qualitative and mixed methodologies. Oxford: Oxford University Press.

Foucher, A. (2010). Didactique des langues-cultures et Tice: scénarios, tâches, interactions. Education, 81-90. Université Blaise Pascal-Clermont-Ferrand II.

Freschi, A. C., \& Lopes, Q. B. (2016). Potenciais sequências de aprendizagem intercultural no teletandem: a importância da mediação. Revista do GEL, 13(13), 49-74. https://revistadogel.emnuvens.com.br/rg/article/view/1470

Garcia, D. N. M. (2015). A logística das sessões de interação e mediação no teletandem com vistas ao ensino/aprendizagem de línguas estrangeiras. Estudos Linguísticos, 44(2), 725-738.

Gonçalves, S. C. L., \& Tenani, L. E. (2008). Problemas teórico-metodológicos na elaboração de um sistema de transcrição de dados interacionais: o caso do projeto ALIP (Amostra Linguísticas do Interior Paulista). Niterói, 25, 165-183. http://www.gragoata.uff.br/index.php/gragoata/article/viewFile/236/221

Hafner, C. A. (2018). Genre innovation and multimodal expression in scholarly communication: video methods articles in experimental biology. Ibérica, 36, 15-42.

Helm, F, \& Guth, S. (2010). The multifarious goals of telecollaboration 2.0: theoretical and practical implications. In F. Helm \& S. Guth (Eds), Telecollaboration 2.0: language literacies and intercultural learning in the 21st century. Peter Lang.

Lopes, Q. B. (2019). MULTEC: a construção de um corpus multimodal em teletandem. Doctoral dissertation. 
Luz, E. B. P. (2012). Variáveis influenciadoras da continuidade ou descontinuidade de parcerias de teletandem à luz da teoria da atividade. Doctoral dissertation. https://repositorio.unesp.br/bitstream/handle/11449/103516/luz_ebp_dr_ sjrp.pdf?sequence=1\&isAllowed=

Marcuschi, L. A. (2003). A transcrição de conversações. In L. A. Marcuschi (Ed.), Análise da Conversação (5th ed.) (pp. 9-13). São Paulo, SP: Editora Ática.

Miller, C. R. (1984). Genre as social action. Quartely Journal of Speech, 70, 151-167. https://www.researchgate.net/ publication/238749675_Genre_as_Social_Action

Moreno, A. I., \& Swales, J. M. (2018). Strengthening move analysis methodology towards bridging the function-form gap. English for Specific Purposes, 50, 40-63.

O’Dowd, R. (2018). From telecollaboration to virtual exchange: state-of-the-art and the role of UNICollaboration in moving foard. Journal of Virtual Exchange, 1, 1-23. Research-publishing.net. https://doi.org/10.14705/rpnet.2018. jve.1

Rampazzo, L. (2017). Gêneros textuais e telecolaboração: uma investigação da sessão oral de teletandem inicial. Master's Thesis. https://repositorio.unesp.br/bitstream/handle/11449/150055/rampazzo_l_me_sjrp. pdf? sequence=3\&isAllowed $=y$

Rampazzo, L., \& Aranha, S. (2018). A sessão oral de teletandem inicial: a estrutura retórica do gênero. DELTA: Documentação e Estudos em Linguística Teórica e Aplicada, 34(1), 449-473.

Silva, J. M. (2012). Projeto teletandem Brasil: as relações entre as comunidades virtuais, as comunidades discursivas e as comunidades de prática. Master’s Thesis. https://repositorio.unesp.br/bitstream/handle/11449/93891/silva_jm_ me_sjrp.pdf?sequence $=1$

Swales, J. M. (1990). Genre analysis: English in academic and research settings. Cambridge: Cambridge University Press.

Swales, J. M. (2004). Research genres: exploration and applications. Cambridge: Cambridge University Press.

Swales, J. (2009). Sobre modelos de análise do discurso. In B. Biasi-Rodrigues, J. C. Araújo \& C. T. S. Socorro (Eds), Gêneros textuais e comunidades discursivas: um diálogo com John Swales (pp. 33-46). Belo Horizonte, MG: Autêntica Editora.

Telles, J. A. (2006). Projeto Teletandem Brasil: Línguas Estrangeiras para Todos - Ensinando e Aprendendo línguas estrangeiras in-tandem via MSN Messenger. Faculdade de Ciências e Letras de Assis, UNESP.

Vassallo, M. L., \& Telles, J. A. (2006). Foreign language learning in-tandem: theoretical principles and research perspectives. The ESPecialist, 25(1), 1-37. http://citeseerx.ist.psu.edu/viewdoc/download?doi=10.1.1.845.2443\&rep= rep1\&type=pdf

Warschauer, M. (Ed.). (1996). Telecollaboration in foreign language learning: proceedings of the Hawaii Symposium. Honolulu, HI: Univeristy of Hawaii Second Language Teaching and Curriculum Center. 


\section{Appendix}

\begin{tabular}{|c|c|c|}
\hline \multicolumn{3}{|l|}{ Annotation system } \\
\hline Occurrences & Sinals & Examples \\
\hline Names in turn-taking & $\begin{array}{l}\text { "E" for the participant from the American university and } \\
\text { "B" for the participant from the Brazilian university }\end{array}$ & E; B \\
\hline Participants' names & We use a code (TI - Teletandem identification) for each participant & I9F3 \\
\hline Participants' e-mails & We insert an explicative note in square brackets & [19F3's email] \\
\hline $\begin{array}{l}\text { Names of people related } \\
\text { to the participants }\end{array}$ & $\begin{array}{l}\text { We add a letter to the TI code corresponding to the relationship } \\
\text { with the participant, such as "p" for father ("pai” in } \\
\text { Portuguese), "m” for mother, "av" for grandparents ("avós" } \\
\text { in Portuguese), "n” for boyfriend/girlfriend ("namorado/a" } \\
\text { in Portuguese), "a” for friend (“amigo/a” in Portuguese) }\end{array}$ & I9F3p \\
\hline University names & These are not anonymized & UNESP; UGA \\
\hline City/town names & We insert an explicative note in square brackets & $\begin{array}{l}\text { [town where s/he lives] } \\
\text { [town s/he visited] }\end{array}$ \\
\hline Numerals & Numerals are written down & Ten; twenty \\
\hline Interrogative tone & Question mark & $?$ \\
\hline Exclamative note & Exclamation mark & $!$ \\
\hline Interjections & Interjections are written down & ah; hum; ahn \\
\hline Citation & Between quotation marks & $\begin{array}{l}\text { Magsamen disse "When I } \\
\text { grow up, I want to be me" }\end{array}$ \\
\hline Overlapping & Between square brackets we add participant’s turn & B: and then I [E: you... \\
\hline Interruption & We insert the word "interrupts" between square brackets & B: [interrompe] \\
\hline Truncated speech & Slash & I/I bou/bought \\
\hline Pauses & Ellipsis & $\ldots$ \\
\hline Emphasis & Capital letters & Do you BELIEVE? \\
\hline Inaudible excerpt & We write "inaudible" in square brackets & [inaudible] \\
\hline $\begin{array}{l}\text { Analyst's comment or } \\
\text { image description }\end{array}$ & Comment or description in double square brackets & [[ ]] \\
\hline
\end{tabular}

Adapted from MARCUSCHI, L. A. A transcrição de conversações. In Análise da Conversação (5.ed.). São Paulo: Editora Ática, 2003; and GONÇALVES, S. C. L; TENANI, L. E. Problemas teórico-metodológicos na elaboração de um sistema de transcrição de dados interacionais: o caso do projeto ALIP (Amostra Linguística do Interior Paulista). Niterói, 25, 2008, 165-183. 
Published by University of Groningen Press | UGP, a not-for-profit association Groningen, The Netherlands I UGP@rug.nl

(c) 2019 UNICollaboration (collective work)

(C) 2019 by Authors (individual work)

Journal of Virtual Exchange 2019

Edited by Carolin Fuchs, Cecilia Kennedy, and Muge Satar

Publication date: 2019/10/17

Journal of Virtual Exchange (JVE) is an online, open-access, peer-reviewed journal aimed at practitioners and researchers in the field known variously as virtual exchange, telecollaboration, or online intercultural exchange. It is the official journal of UNICollaboration (https://www.UNICollaboration.org/), the international academic organisation dedicated to supporting and promoting telecollaboration and virtual exchange in higher-level education.

Rights. The whole volume is published under the Attribution-NonCommercial-NoDerivatives 4.0 International licence (CC BY-NC-ND 4.0); individual articles may have a different licence. Under the CC BY-NC-ND licence, the volume is freely available online (https://doi.org/10.14705/rpnet.2019.jve) for anybody to read, download, copy, and redistribute provided that the author(s), editorial team, and publisher are properly cited. Commercial use and derivative works are, however, not permitted.

Disclaimer. University of Groningen Press does not take any responsibility for the content of the pages written by the authors of this article. The authors have recognised that the work described was not published before, or that it was not under consideration for publication elsewhere. While the information in this article is believed to be true and accurate on the date of its going to press, neither UniCollaboration nor University of Groningen Press can accept any legal responsibility for any errors or omissions. Additionally, the publisher makes no warranty, expressed or implied, with respect to the material contained herein. While University of Groningen Press is committed to publishing works of integrity, the words are the authors' alone.

Trademark notice. Product or corporate names may be trademarks or registered trademarks, and are used only for identification and explanation without intent to infringe.

Copyrighted material. Every effort has been made by the editorial team to trace copyright holders and to obtain their permission for the use of copyrighted material in this article. In the event of errors or omissions, please notify the publisher of any corrections that will need to by incorporated in future editions of this article.

Typeset by Research-publishing.net (https://research-publishing.net/)

Noto fonts are open source. All Noto fonts are published under the SIL Open Font License, Version 1.1. Noto is a trademark of Google Inc. (https://www.google.com/get/noto/).

ISSN: 2647-4832 (online only) 